\title{
Water System Management in Emergency Situations
}

\author{
Milan Lindovsky ${ }^{1}$ and Sarka Krocova ${ }^{2}$ \\ 1. VAE CONTROLS Group, a.s., Namesti Jurie Gagarina 233/1, Ostrava 710 00, Czech Republic \\ 2. Faculty of Safety Engineering, Technical University of Ostrava, Lumirova 13, Ostrava 700 300, Czech Republic
}

\begin{abstract}
This article deals with the issue of water system management and emergency management of water supply systems based on experience with the operation of water systems in EU (European Union) Member States. The options available for prevention/elimination of the hazard of limited drinking water supply to the public are described. Current climate and, in some countries, also the existing social conditions pose barriers to a smooth water supply to the public. Various hazards endangering the quality and amounts of water produced emerge. Since the risk of water supply outages due to natural or anthropogenic factors cannot be completely eliminated (for instance, hacker attacks pose a new threat to the water companies' control systems), in other words, emergency situations where smooth water supply is disturbed cannot be ruled out, efforts must be made to at least minimise adverse impacts of such events on the users. Organisational and technical conditions minimising such hazards must be set up. A water production and distribution organization and management system must be introduced, which will be able to prevent and address such hazards and emergency situations. How to tackle this complex task in the real water system management conditions and to assure some minimal amount of water at least for strategic consumers is discussed in this article. The results of a water system operation risk analysis are presented, feasible methods to minimize such risks are described, and options to prevent and address such risks are proposed. A water company organisation and management system taking into account the possibility of development of emergency situations is set forth. Focus is on the use of a telemetric system as a system means that facilitates the prevention and possible addressing of any emergencies occurring during the operation of a water supply system.
\end{abstract}

Key words: Emergency, emergency water supply, water system management, hydraulic efficacy of the water supply system, monitoring and telemetric system.

\section{Introduction}

The problem of water supply to the public is an inseparable part of the environment and infrastructure of every state. The progressing development of industrial production and increasing social standard of the public (the majority of whom live in towns and cities without direct access to water) are accompanied by increasing requirements for smooth water supply by water works and water distribution systems.

Water supply lines for public needs in the European Union supply drinking water to $72 \%$ to $100 \%$ of the population of the Union states (in total, 507.4 million citizens live in the European Union).

In the Czech Republic (with the population of 10.5 million) that forms part of the European Union, almost

\footnotetext{
Corresponding author: Milan Lindovsky, MBA, research field: safety of water supply. E-mail: milan.lindovsky@vaecontrols.cz.
}

93\% inhabitants are dependent on public water supply lines; more than 600 million $\mathrm{m}^{3}$ of drinking water are produced annually, while losses of the produced drinking water due to facility failures and pipeline leakages amount to $17 \%$ of the total volume of produced drinking water, or in other words, $8.6 \mathrm{~m}^{3}$ of water/one kilometre of water supply lines/one day (water losses in the European Union amount to 5-60 $\mathrm{m}^{3} /$ kilometre/day depending on the technical standard of water systems of the given EU country) [1]. For example, these losses can be expressed as 30 litres daily per inhabitant in the Czech Republic. Almost 2,000 water supply companies are engaged in the production of drinking water and its distribution to inhabitants and strategic consumers (food producers, medical and social institutions, hospitals, etc.) [1]. As follows from this statistical information, water supply systems should be operated in a way that will minimise 
technological losses of water in pipelines while at the same time limiting origination of an emergency situation that would result in further operating losses of water, or that would even limit water supplies to end consumers. These facts, with a wider range of supplied inhabitants, could result in a disastrous impact on social and technical infrastructures of the whole state.

Thus not only legislative protection, but also actual protection of water supply lines and water systems in real practice must correspond to the given strategic importance of water supply lines. Such organizational and technical modes of management and operation of water systems should be created and applied, which will support reliable and safe production and distribution of drinking water to the public and minimise any hazard of emergencies. At the same time, safety measures stipulated in the documents WHO [2] and IWA [3] must be observed.

\section{Evaluation of the Risks of Water Systems}

In general, the weak point of water systems is a lack or insufficient number of redundant technical facilities and water system operation variants, and an inadequate level of automation and water mains equipment with telemetric facilities. A detailed analysis of conceivable risks associated with the operation of water supply systems is presented, e.g., in Ref. [4].

This is a major factor at minor water supply systems at the level of municipalities or associations of municipalities, where inadequate funds were invested and the technological level of the systems was underestimated as a consequence of water pricing set at socially acceptable levels in the Czech Republic.

With basic knowledge of the above mentioned essential risks depending on the type of production and operation facilities and a whole scale of other technological elements of the water supply system [5], every water supply company is able to choose an optimum method to reduce the risk of an emergency. This procedure should be anchored in internal standards of any given water supply company, for example, in the so called Emergency Preparedness Plan, and at the same time, it should be linked to the general emergency plan of the region and state.

Based on available information [6], the following components of the water system currently emerge as the highest-risk points from the operational aspect:

- Power supply to the technological equipment;

- Mechanical systems of the water mains (valves and chambers);

- Fire hydrants (water withdrawal points from the mains);

- Aeration technology (water treatment technology);

- Chlorination technology (water treatment technology);

- Telemetric and control system.

\section{Emergency Situation Development Risk Reduction}

The risk of occurrence of an emergency situation in water production and distribution resulting in insufficient water supply to the water system users cannot be completely eliminated. The likelihood of such situations increases together with growing civilizational influences; their intensity and probability are governed by many natural laws and rules and sometimes are affected by humans and human activities. Since the occurrence of an emergency situation cannot be ruled out, efforts must be made to reduce its negative impacts to an acceptable level.

Taking into account the factors described above, basic types of provisions reducing the impacts of the risks can be identified as follows [7]:

(1) In standard operating conditions:

- Setting up a mathematical model of the water supply network for designing and analysis of the operational states;

- Designing the water supply network so as to inherently include safety elements in the technological solution itself;

- Building up a monitoring and control system for 
the entire water supply network or for its strategic segments;

- Use of a suitable type of the distribution piping and technological equipment;

- Optimisation of the safety and measuring elements in various segments of the water supply network;

- Development of basic scenarios to address the management of operational accidents within the emergency plan;

- Development of a logistic approach to substitute drinking/service water supplies;

- Development of methodology for running water supply plants and networks.

(2) During emergencies and crisis situations [8]

- Emergency planning, development of the water company's emergency preparedness plans;

- Design of organisational and management structures for water management in emergency situations;

- Identification of critical elements in the technological infrastructure and their priorities in water delivery;

- Material and logistic preparation for an emergency, i.e. analysis of the needs for material stocks, purchase and appropriate storage of stocks depending on the importance and nature of the building structure endangered, signing agreements on the loan of technological equipment or on the form of emergency assistance;

- Use of the telemetric and control system for the variant and emergency management of the water supply system.

This topic reaches beyond the scope of this paper and so only the basic conditions and proposals for approaches to emergency situations are discussed here.

\subsection{Emergency Drinking Water Supply}

Ensuring of emergency drinking water supplies for hundred thousands of inhabitants and national infrastructure entities has not been tested yet in the
Czech Republic. Only theoretic assumptions are used as the basis, i.e. that the inhabitants would be supplied with packaged water in amounts determined by the law, and any drinking water deliveries from collection points within the operated part of the water supply network. As regards emergency services of water supply and other entities of the national infrastructure, it is followed from the assumption that water supplies for their activities would be ensured by the water system operator and an appropriate community or town.

The given theoretic assumption bears an extraordinary risk without any further analyses of real capacities of drinking water production and distribution systems, and moreover very difficult to additionally address in an actual emergency situation. It is predominantly followed from the assumptions of capacities of water sources, inhabitant numbers in the given region, need of water for emergency supplies in various time segments, and technical means of various entities that can participate in addressing the situation. A number of hazards and risks are omitted that could modify the assumptions of direct emergency supplies of drinking water from the water supply network to the detriment of the envisaged solutions.

Major technical risks affecting water supplies include [10]:

- Type of the water source and geographic ruggedness of the territory with respect to pressure zones of water mains and locations of water accumulation areas (water towers);

- Hydraulic efficacy of distribution networks (water losses from hidden leakages);

- An essential change in hydrodynamic pressure conditions in the network in the event of a lack of water from substitute sources depending on hydraulic efficacy of the network;

- The need of direct water supplies from the water supply network with the usual or slightly reduced hydrodynamic pressure for entities of critical infrastructure whose technologies and operations fully 
depend on such supplies;

- An increased risk of secondary contamination of the distribution system of drinking water, and of underpressure in parts of facilities with reduced amounts of supplied water;

- Absence or insufficient management and monitoring systems of water distribution and water quality that would support emergency management of water supply facilities;

- Insufficient protection of water sources, water system objects, and power and management systems of water mains.

Most water supply companies are not yet ready for such situations in terms of organization and technology; they lack a coherent solution concept and prepared binding methodology.

Therefore this paper suggests a solution of risks that could substantially disturb emergency supplies of drinking water to strategic consumers.

Given that the described problems exceed the scope of this paper, only a listing of essential proposals of solutions of extraordinary and emergency situations is provided.

\subsection{Optimisation of the Water Piping Sizes}

Exceedingly important system requirements in water supply network construction include optimisation of the sizes of the water piping and related equipment based on real water needs $\&$ prediction of the water use trend to a 50-year horizon (which is the expected service life of a water distribution system). Such a status can be achieved by conventional water supply network calculations or by mathematical modelling [9]. Mathematical modelling is convenient when designing and building new water distribution systems because it allows us to define the required hydraulic situation for the various water supply network segments. A number of design data must be known for mathematical modelling. The most important of them are:

- Water mains sizes (piping diameters);

- Actual length of the water pipeline segments;
- Number of control valves within a given water main segment;

- Pipe material type (internal friction resistance).

Existing software products can be used when setting up the mathematical model.

When building a water distribution system, the material must be selected with regard to the soil layer composition and weather conditions.

\subsection{Hydraulic Network Efficiency with Respect to Emergency Drinking Water Supply}

The major current problem of the extensive and often very old water supply networks in the majority of Czech cities and towns is their actual hydraulic efficiency due to hidden water leaks from the water supply system. A precondition for reducing the risk is thorough knowledge of the hydraulic efficiency of the system as a whole as well as of the system segments and pressure zones. The mean system efficiency levels which are based on the difference between the amounts of water fed to the supply system and the amounts billed to the consumers and are currently employed for planning purposes are unusable when addressing emergency situations. In fact, the only usable information includes data from technical measurements on the network segments, typically the monitoring zones [5].

Spectral analysis of water flow through a section of the water supply network provides data enabling us to ascertain if emergency drinking water supplies to the critical infrastructure entities can be ensured even if reduced amounts of water are fed to the network. If the results of measurement indicate a discrepancy between the need and reality, the causes of the current status must be analysed. This can be achieved in various ways by employing detection instrumentation for identification of hidden water leaks (see Fig. 1).

\subsection{Emergency Drinking Water Supply to Entities of the Infrastructure}

Water companies that are not yet equipped with the 


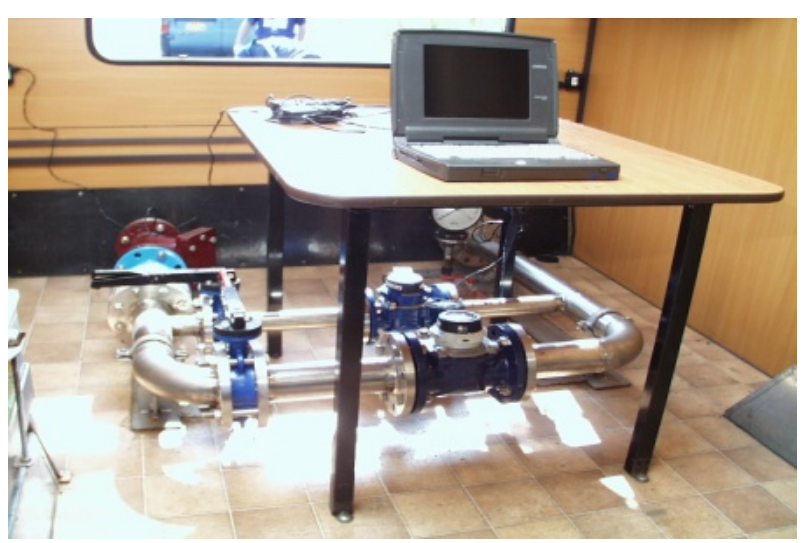

Equipment for mobile measurements of the volumetric and flow parameters

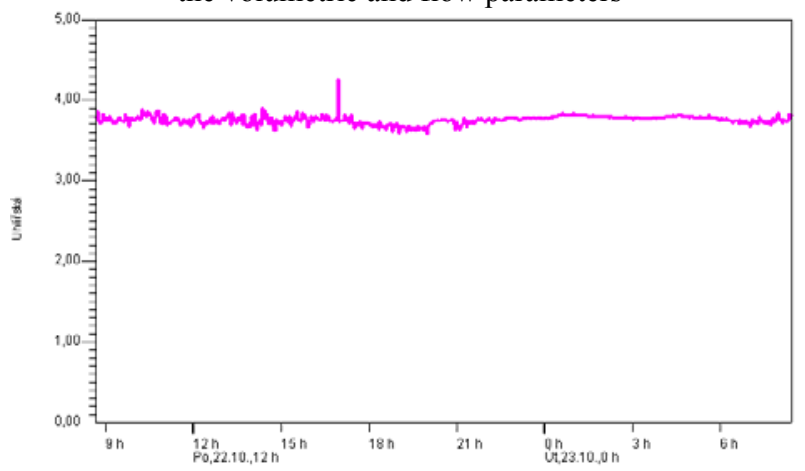

Monitoring zone with high water losses in the system

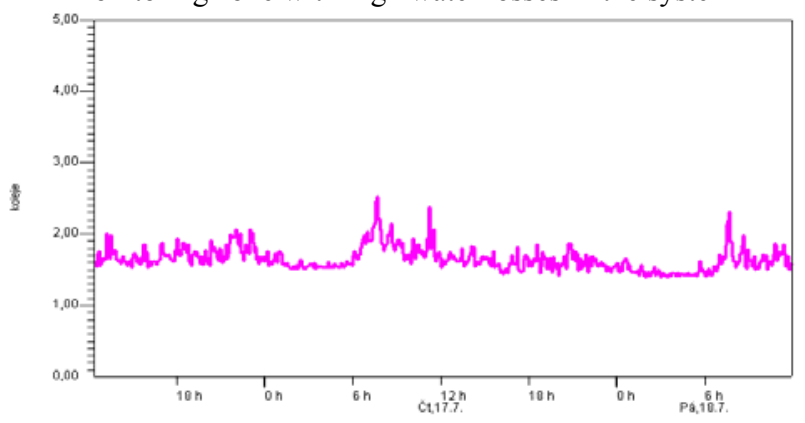

Monitoring zone following partial water loss reduction

Fig. 1 Hydraulic efficiency analysis for a water supply network with respect to emergency water supply.

above monitoring instrumentation should preferably use an alternative approach. One of the reasonable options, shown in Fig. 2, is the reduction of the water supply network length to segments of prime importance (shown in red in the figure), which will ensure drinking water supply to selected consumers only and basic fire water supply to selected withdrawal points.

For the water supply system length reduction to satisfy the purpose, a number of facts at the site must be respected not only from the water system operator's point of view but also from the strategic water consumers' point of view. Such parameters include but are not limited to:

- Capacity of the replacement water resources;

- Standard water consumption within the reduced segment;

- Actual water losses (in litres per second) within the reduced water mains segment, also with respect to the replacement water resource capacity;

- Total drinking water consumption by the strategic consumers in normal conditions and the minimal requirements to be considered in emergency scenarios;

- Opinions and requirements of fire brigades regarding the amounts of fire water and locations where withdrawal points are really necessary.

If the summary requirements for emergency water supply within the reduced water distribution system segment exceed the emergency resource capacity, the reduction efforts must continue in the following chronological order [11]:

Close the normal water users' branches and leave open only the strategic users' branches. Install only outflow stands at suitable sites for emergency water supply to the public;

Perform additional analysis of the hydraulic situation in the network and identify and eliminate additional hidden leaks so as to reduce leaks nearly to zero;

Fit the water mains with reduction valves before any emergency occurs if the normal hydrodynamic pressure level in the water supply system is higher than $0.3 \mathrm{MPa}$. Reduce water pressure in the system during an emergency situation.

\section{Proposal of a System to Monitor and Control Water Systems during Emergency Situations}

The capacity to operatively monitor and control the system is an exceedingly important factor in emergency preparedness provisions to retain the ability to supply drinking water to the consumers. This 


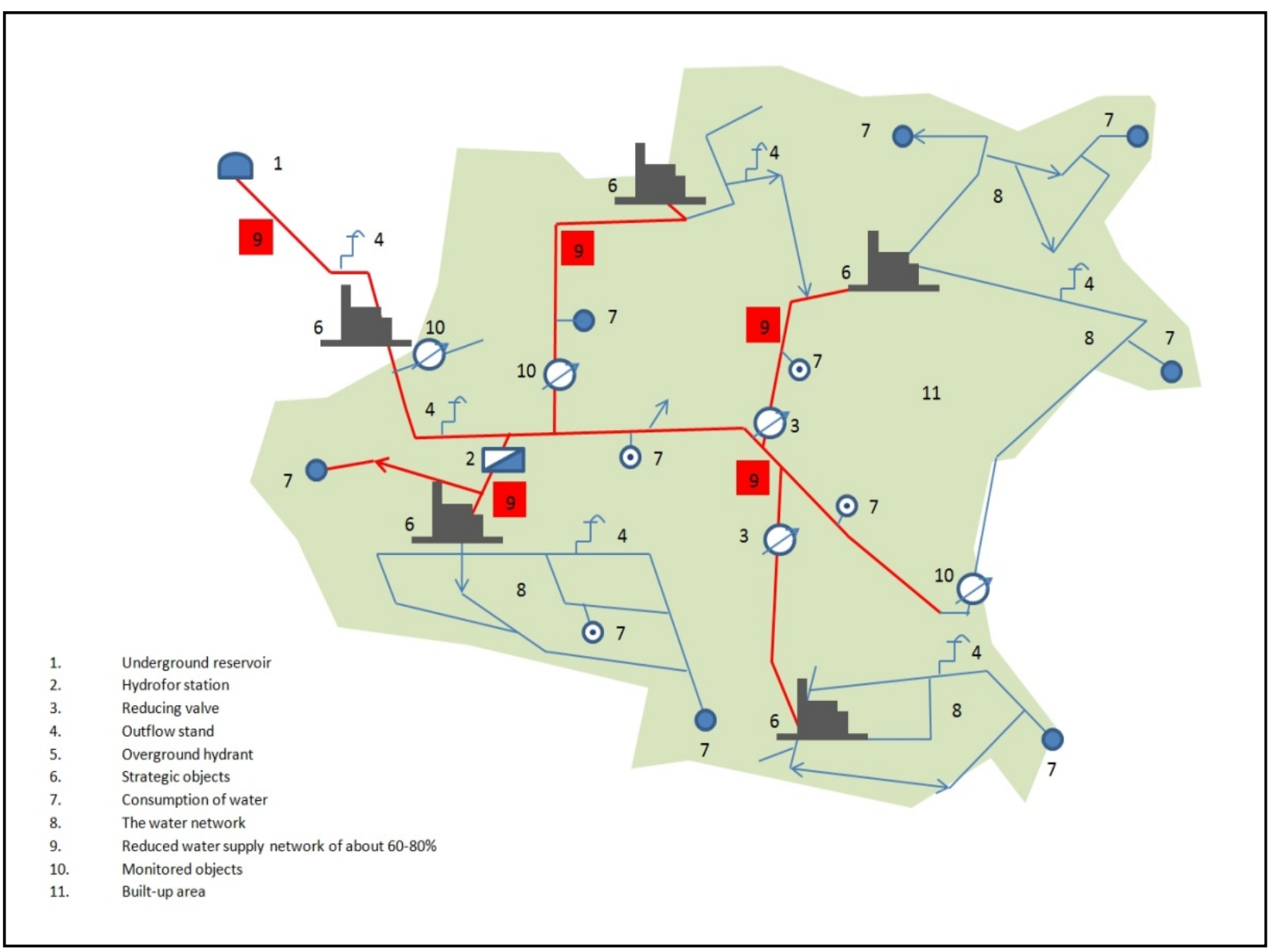

Fig. 2 Sample solution for network reduction adequate to ensure emergency water supply and fire safety.

requirement is best satisfied by remote control of the water mains' strategic valves, online monitoring of instantaneous water flow rates at various points of the network and in various pressure zones and hygienic water parameters before entering the water distribution system. Remote measurement of the input elements and transmission of safety information (manholes, doors, fencing, etc.) from technological structures with free drinking water level is a safety measure which must be implemented (and is a standard measure today). This minimises the danger of wilful water contamination in water reservoirs (terrorist attack). Transmission of photographs of the structures is also beneficial.

In order to facilitate operative management, water supply systems (each represented by one or more interconnected water mains) must be interlinked into one joint control system consisting of a central supervisory control facility \& a system of local monitoring elements. The entire telemetric system must be interlinked by means of a private radio network or the public GPRS network.

In emergency situations, the control centre as an integral component of the water company's organisational structure should coordinate the activities within the ERP system. Organisational and logistic links of the supervisory control facility within the company's information system are shown in Fig. 3.

Effective monitoring and ability to remotely control the water system structures is a basic precondition for successful management of water mains in an emergency situation where an inadequate water supply danger is imminent. The technical level of monitoring governs the ability to predict an emergency and, at the same time, to promptly respond to the unfavourable operating condition, thereby reducing the probability 


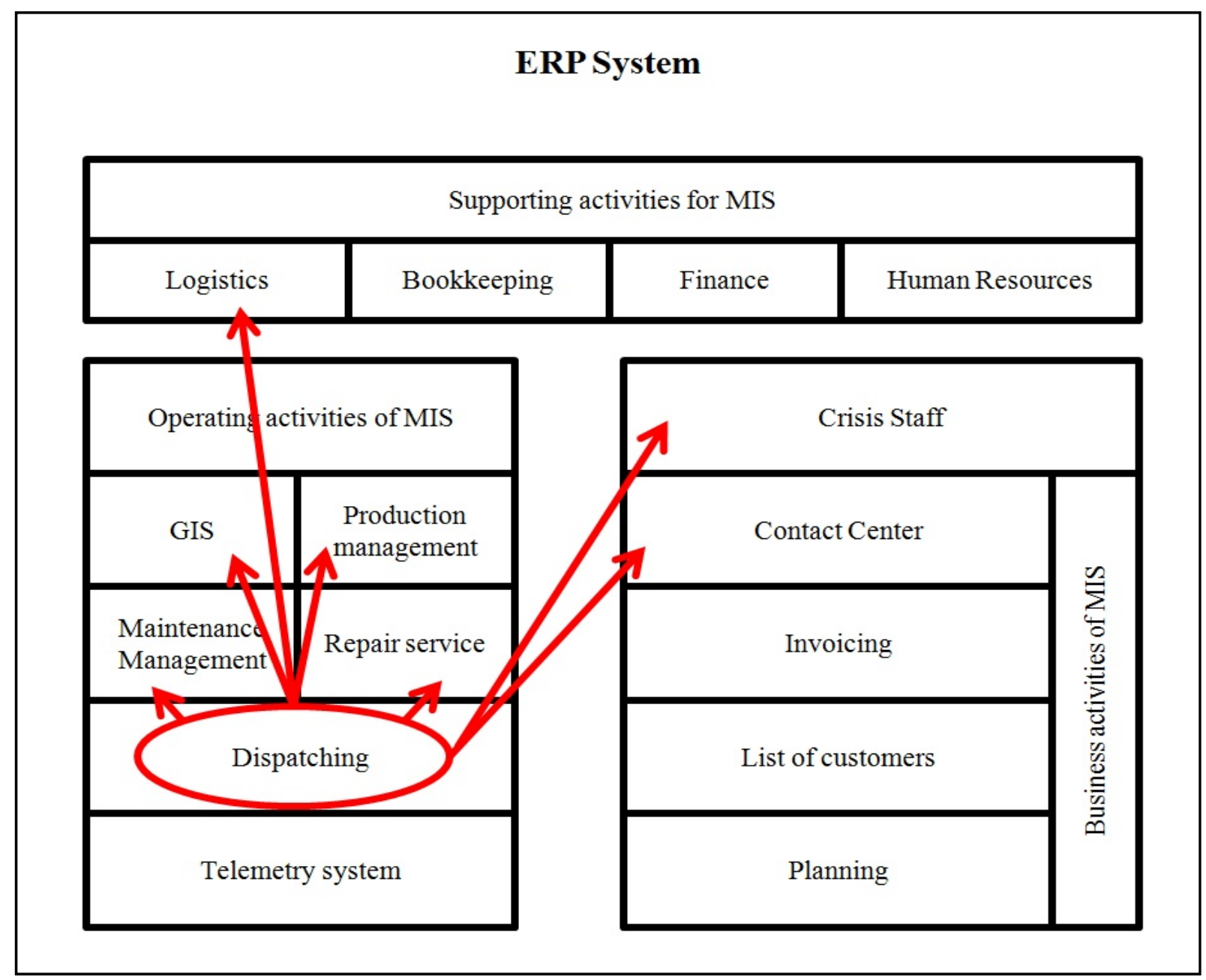

Fig. 3 Organization of the control centre in case of emergency [18].

of primary and secondary damages of various types. Hence, the use of modern telemetric systems in this part of water management process control is imperative [12].

The scope of this paper does not permit all the requirements for monitoring of the various parameters of the technological processes and equipment to be described. For illustration, only an example of distribution network monitoring and the feasibility of water leak monitoring at the water mains piping is presented below.

\subsection{Monitoring of Drinking Water Distribution Systems}

The water mains network is undoubtedly one of the most vulnerable parts of the production and distribution system. The risk of secondary drinking water contamination usually arises during accidents and in settings where the safety and security principles and operational rules fail to be duly complied with. The risk of uncontrolled spreading of the drinking water contamination can be reduced particularly through the following measures:

- Online monitoring and evaluation of the amounts of water actually present in the distribution network, pressure zones, sections or monitoring zones;

- Monitoring/remote control of the performance of pressure regulating valves (night/day modes), repumping stations or pressure stations and other technological structures;

- Remote control of strategic valves at the feeders, backbone lines and selected points of the water supply distribution network. 


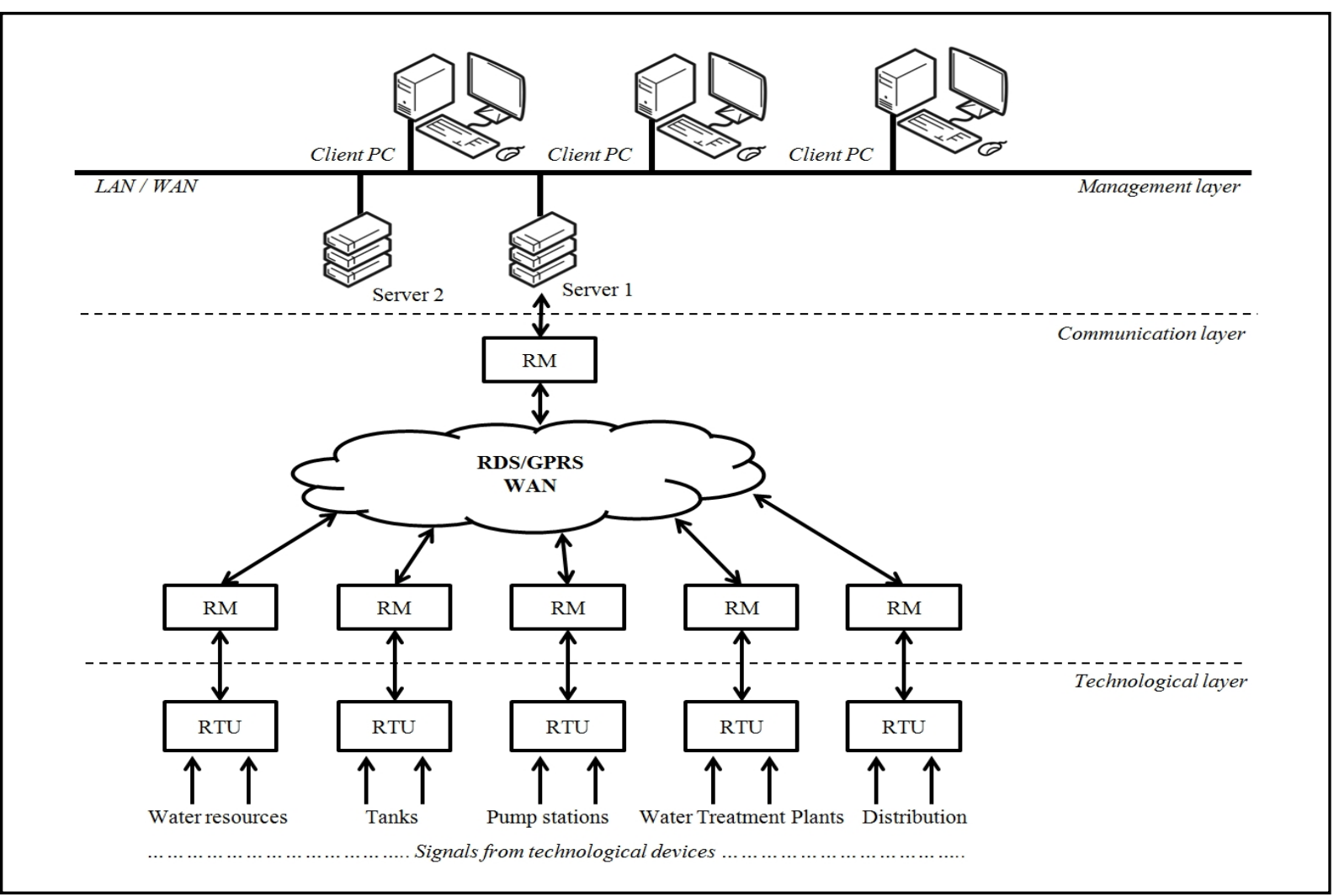

Fig. 4 Layout of the water supply control system communication links [8].

$\mathrm{RM}$ - private radio network; RTU—remote telemetry unit.

\subsection{Water Leak Detection}

Operation of any water distribution system is associated with water losses. Such losses cannot be completely eliminated, they can only be reduced to an economically acceptable level. Failures that are most difficult to handle are hidden failures where water leaks from the pipeline directly into the subsoil and cannot be seen on the surface. Water supply system operators should have in place a leak detection plan where the water supply network is divided into control measurement segments with respect to the frequency of failures. In addition to pressure and flow rate measurements, specific failure measurements are made by using special equipment or by applying mathematical methods.

The main measuring methods include [13]:

- Night flow rate regime monitoring;

- Audio monitoring of the valve network;

- Balance zones;
- Network correlation.

\section{Proposal of Operational and Operative Provisions in Water Supply Structures}

As outlined above, the following design and technical preconditions must be created at the level of the water supply system and of the operating water company for operationally and economically successful management of emergency situations [11]:

- Taking into account the capacity of the water mains system for the needs of the population, technical entities of the infrastructure and fire safety of the built-up areas;

- Adequate water resources capacities and numbers;

- Technological interconnection of all the water supply branches and systems.

Satisfaction of those basic requirements for the design and construction of water supply systems as a precondition for effective emergency management creates space for subsequent organisational and 
technical control of the water system so as to prevent or manage emergencies.

A next requirement for effective management of emergencies on the water supply system is the existence of a unified water company management system. This management domain is not adequately addressed so far. A unified approach to, and flexibility of emergency management are not applied.

In order to introduce such a unified system, the water system operator must create an organisational and management structure consisting of:

- Emergency management team (consisting, e.g., of the process manager, chief engineer, company top management representative, financial manager and head of the supervisory control centre) to manage the emergency situation, organisational and working relations, contact with the owners and with the municipal emergency teams, fire brigade, etc.;

- Technical equipment (measuring, portable, computer and control instrumentation) comprising a telemetric control system within a devised scope;

- ERP (Enterprise Resource Planning) system; GIS (Geographic Information System);

- Information and data support (handling rules, emergency preparedness plans, design documentation, decision-making supporting software, i.e. management emergency information safety system (MISMI)) [18].

Organisational structure of the system proposed is shown in Fig. 5.

Such a management organisation system, including the above proposal for organisational-technical preventive measures to minimise the risk of emergencies or to efficiently manage existing emergencies, should result in better:

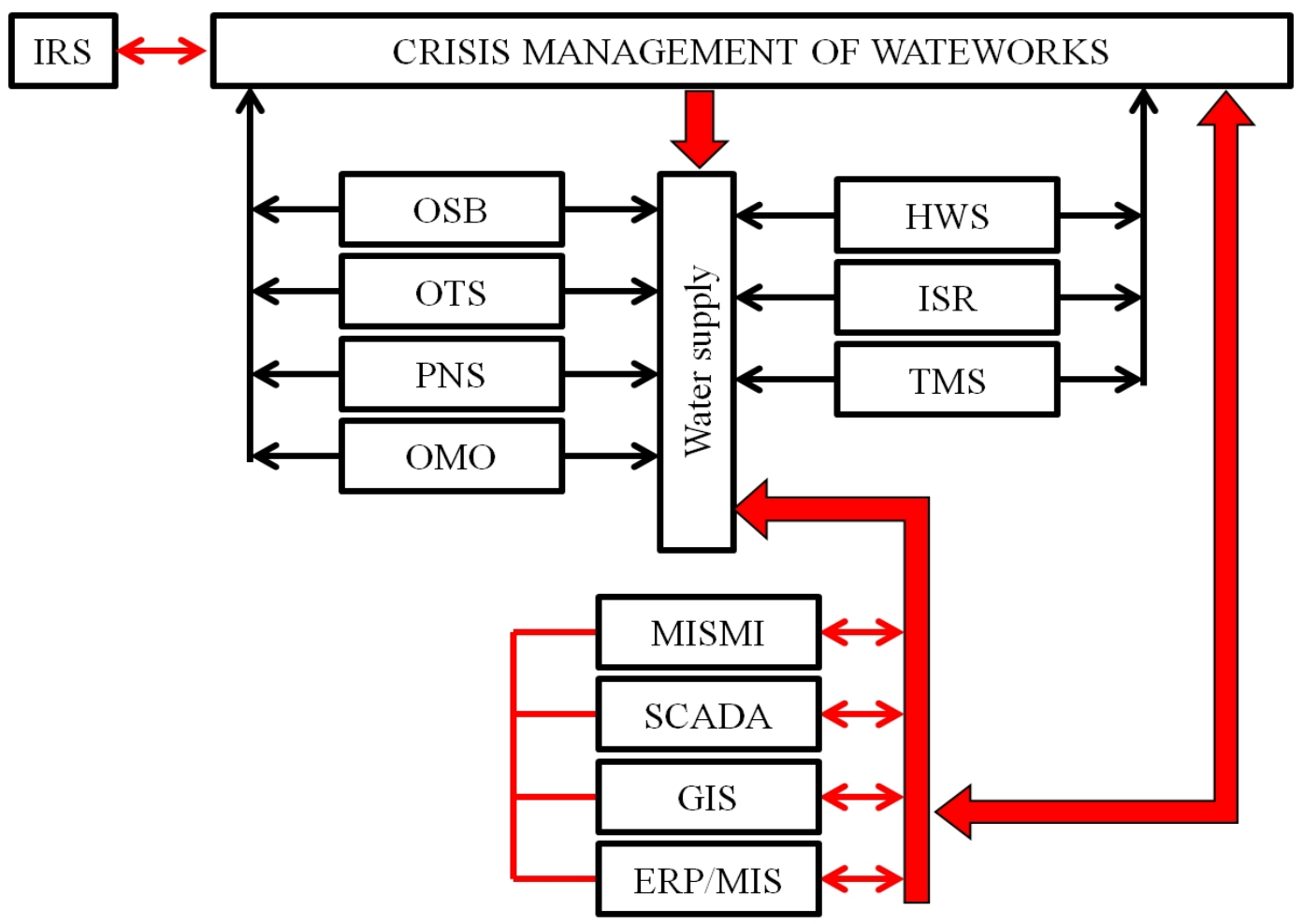

Fig. 5 Proposal for emergency management organisation [18].

Legend: OSB — operational safety of buildings; OTS — organizational safety; PNS — personnel safety, OMO — operative management organization; HWS - resistant hydraulic water supply system; ISR—information security; TMS-telemetry system; MISMI — management information safety system; SCADA — dispatching system;

GIS - geographic information system; ERP—enterprise information system; IRS—integrated rescue system. 
- Physical security of the structures (buildings);

- Information safety of the company networks;

- Personal safety of the water supply systems;

- Organisational safety of the water company;

- Hydraulic resistance of the water supply system;

- Quality of the operative management of the process;

- Monitoring efficiency;

- Unification and adaptability of the information system;

- Effective management of existing emergencies.

Specific application of the proposals to local conditions and their introduction into the water industry will reduce the risk of emergency situations and create preconditions for effective management of an emergency situation should any occur, with the aim to minimise social and economic harm.

\subsection{Physical Security of the Structures (Buildings)}

This section of the proposal sets out requirements for the parts of the physical security system as a means to ensure physical security of the water supply structures (buildings). This includes but is not limited to the following areas:

- Alarm security system;

- Camera system;

- Entrance control;

- Mechanical barrier systems;

- Physical security personnel where appropriate.

Physical barriers, i.e. fencing of the water supply structures and water reservoir areas, combined with information transmitted from the alarm and camera systems to the supervisory control centre can reduce any violent damage of the water technology.

\subsection{Information Safety}

Information safety is a cornerstone in the protection against hacker attacks for the systems of data administered inside databases and information systems and processes that run above those data by means of application equipment. Basic parameters of information safety management include [14]:

- Identification and authentication of access to a SW application through personal passwords;

- Control of the logical access to the system via time limits of work, locked access to selected databases, automatic disabling of idle user accesses;

- Software integrity through upgrading of the operating systems and network components from the manufacturer;

- Data backup and erasing;

- Computer network resistance via redundant network equipment, encoded transmission, firewalls, communication protocols, and antivirus protection tools;

- Use of private communication networks; encoding protocols.

\subsection{Personal Safety}

Ensuring personal safety means to set up a system of training, qualification and reviews of employee recruitment; employee access to the water company information networks and process control systems; testing the employees' knowledge, mental resistance and moral integrity [15]. This includes setting up a system of education and development of personal capabilities and knowledge with the aim to minimise economic and technological consequences of the impacts of any human errors during the management of emergency situations. Every water company should have in place an internal employee education system for emergency situations including training of the behaviour in model situations.

\subsection{Organisational Safety}

Organisational safety encompasses a system of organisational standards and management standards for emergency situations. They include, in particular, the following corporate standards:

- Organisation system with the description of each emergency management position;

- Emergency preparedness plan; 
- Emergency plans and handling rules.

Development of methodological guidelines for upgrading each organisational and management standard is also included.

\subsection{Hydraulic Resistance of the Water Supply System}

Hydraulic efficiency of the drinking water and fire water distribution system plays a major role in situations of too low water volumes in the resources or prolonged emergencies on the water-feeding mains. In order to enable the hydraulic parameters of the water supply network to be measured, the network must be divided into segments based on mathematical modelling at the design stage or the static situation of the offline calculation, geographic situation of the ground with respect to the operator's needs, into hydraulically closed or cascade-arranged units of one segment of the water supply network [16]. Experience shows that the optimum length of the segments is $10-15 \mathrm{~km}$. The segments must be hydraulically separated by means of sectional valves. Each segment inlet and outlet is equipped with a meter whose data are transmitted to the supervisory control centre. The data can be analysed to determine the required pressures and the corresponding amounts of water for normal withdrawal, and based on all that, to calculate the pressures during emergency water supply. The optimum pressure level is 0.3-0.45 MPa (Mega Pascal) [17], suiting the majority of consumers' structures and machinery.

Also, the pressures can be controlled in accordance with the long-term consumption diagrams for various day and night periods, thereby reducing water losses through hidden leaks, not stressing the water network's technological equipment by increased pressure, and so improving the operational economy and technical service life of the equipment.

It is appropriate, within provisions to enhance the hydraulic resistance of the water supply network, to use some of the methods to identify hidden water losses, e.g. by means of an operative night water flow monitoring system. If increased flow rates in the water network segment monitored are obtained, the leak site(s) must be detected and the leak(s) eliminated.

\subsection{Operative Process Management Organisation}

Operative process management organisation comprises a set of measures to create organisational-operative tools allowing prompt and flexible management of emerging situations during operation of the water supply system. This includes but is not limited to the following provisions, included in the emergency preparedness plans [18]:

- Description of the water main parts, i.e. setting up an operative list of the facilities including technical description of each of them, the manufacturer, maintenance intervals, year of acquisition, conceivable repair types, estimated repair durations, spare parts list, estimated delivery times of each part ordered, feasibility of part replacement;

- Categorisation of defects by their impact on water supply, description of the conceivable causes, method of elimination;

- Identification of priorities of technical entities at the water mains with respect to water supply, specification of the entity's requirements for water amount and pressure;

- Processing of the requirements for fire protection of the built-up area of the water supply system part analysed.

In this assignment it is advisable, to the maximum extent available to make use of the capabilities of the company information system and to save each provision (in the digitalised form) to the company information system.

\subsection{Unified Information Management}

A unified company information system is the backbone of the emergency management system proposed. At the water company level this includes setting up an interlinked system consisting of [18]:

- The existing ERP-type company information system; 


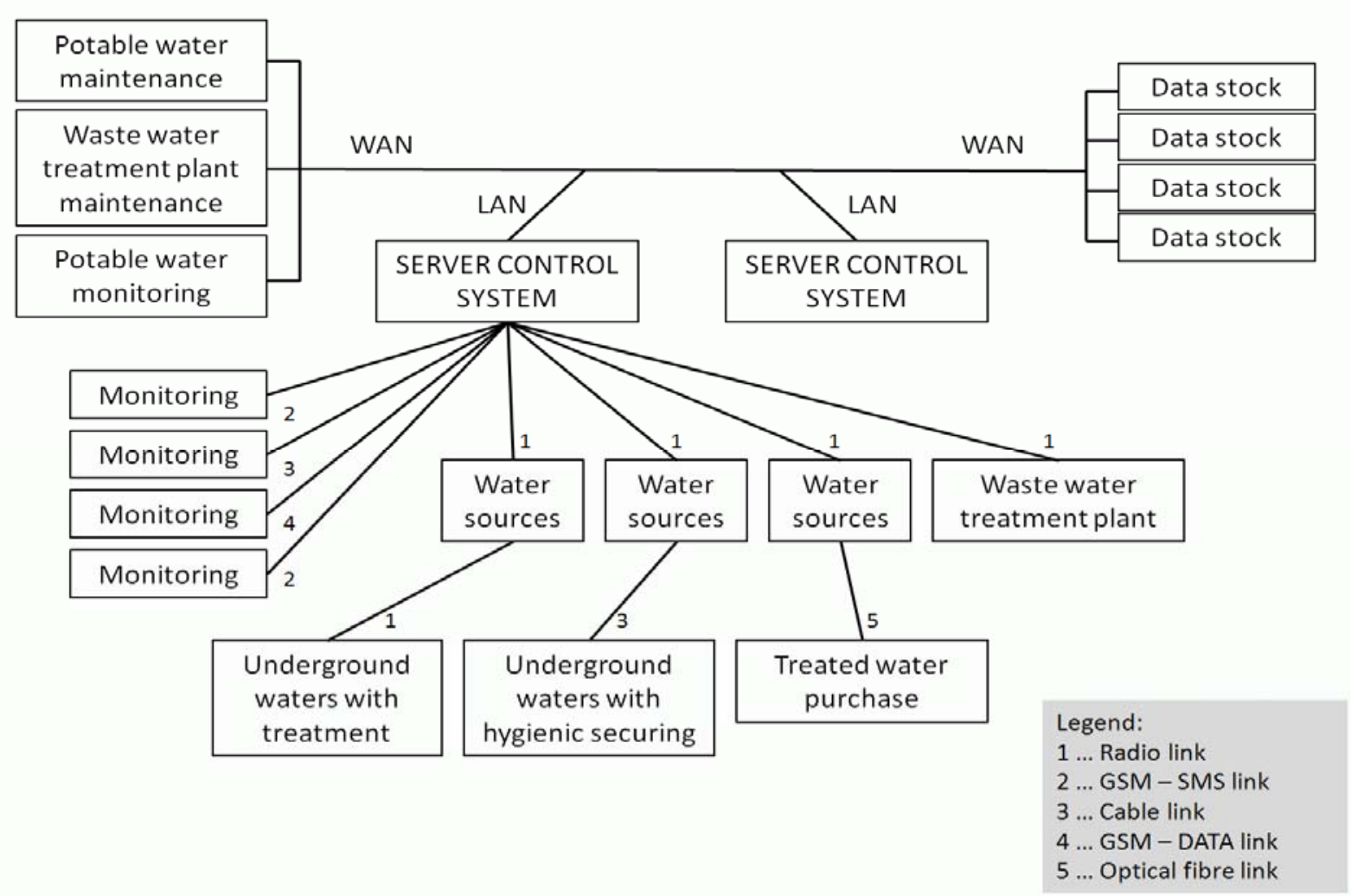

Fig. 6 Alternative diagram of system control of water production and distribution processes [18].

- The GIS completed with the "operational list";

- The telemetric system and the MISMI emergency management system.

Information from the information system so conceived will be available to the company top management, as a supporting tool for decision-making and as a method of communication with the regional/municipal/national integrated rescue system. This system will also support, with the use of technical tools of the supervisory control system, operative management of the water supply network in the emergency mode.

\subsection{Water Supply Network Monitoring}

Water companies largely use a supervisory control centre system for direct control of the water supply network operation. The requirements put on the information scope and on the water supply network management capabilities are multiplied in emergency situations. Managing emergency situations is impossible without remote control of the water technologies, without the possibility of modifying the pressures in the water network, controlling water supply from the various water resources available or regulating water distribution in the water system's replacement branches. The core consists in the monitoring and evaluation of the basic and calculated information from the telemetric supervisory control system:

- Monitoring of major alarms, defects and faults of the water supply system components, technologies and water mains;

- Monitoring of night flow rates and evaluation of uncontrolled water leaks;

- Monitoring of water accumulation in the given water mains;

- Monitoring of hydraulic situation in the water supply network.

If a preset limit for the deviation from the normal operating status is exceeded, the system must generate 
an alarm message about imminent emergency in order to alert the water company's appointed management team.

Subsequently, based on the management decision, the system must allow operative interventions to be made into the water collection/treatment technology and the distribution system, for the various technical entities to be supplied with water based on the drinking water priority scheme and on the technical and capacity capabilities.

A conceivable water system management system is shown in Fig. 6.

\section{Conclusion}

In contrast to the previous decades, adequate operational intuition and personal experience are insufficient to manage a system of water works and water distribution systems. More and more frequently, large areas experience water scarcity, and more and more people depend on central water resources and on water distribution by dedicated water companies. In parallel, energy intensiveness of water production and distribution exhibits an increasing trend. In such situations, preventive design preparation of the water supply management system in case of water scarcity is imperative for the water company top management. The use of monitoring and telemetric systems as a technical basis for emergency situation prevention and management is more urgent then. Telemetric systems as well as the supervisory control centres play an irreplaceable role in running cost reduction in water production/distribution and in the operation of the water system in emergency situations such as floods, long drought periods or the danger of terrorist attacks.

This article gives an idea of how to approach this problem and how a water company can prepare for an emergency having potential impacts on its safe and financially efficient operation.

\section{References}

[1] The International Benchmarking Network for Water and Sanitations Utilities (IB-NET). Accessed May 20, 2015. http://www.ib-net.org.

[2] WHO (World Health Organization). 2004. Guidelines for Drinking Water Quality (3rd edition). Geneva: WHO.

[3] IWA (International Water Association). 2004. The Bonn Charter for Save Drinking Water. London, UK: International Water Association.

[4] Tuhovcak, L., Rucka, J., Kozisek, F., Pumann, P., Hlavac, J., and Svoboda, M. 2010. Water Risk Analýza Veřejných Vodovodiu. Brno: Acadamic Publishing CERM.

[5] Krocova, S. 2009. Strategie Dodávek Pitné Vody. Ostrava: SPBI Spektrum.

[6] Indian \& Nortern Affairs Canada. 2006. "Design Guidelines for First Nations Water Works." Indian \& Nortern Affairs Canada. Accessed March 15, 2006. http://www.ainc-inac.gc.ca/enr/wtrúpubs/dgf-eng.pdf.

[7] Krocova, S. 2014. Rizika Provozování Vodárenských a Kanalizačních Systémů. Ostrava: SPBI Spektrum.

[8] Lindovsky, M. 2014. "Anylysis of Crisis Management Water Supply System.” Journal Inzynieria Mineralna 2 (34): 1640-4902.

[9] Rosa, J., and Riha, J. 2013. "Model pro Zmírňování Rizik a Zvyšování Spolehlivosti Vodárenských Soustav." The Science for Population Protection 5 (2): 45-64.

[10] Lindovsky, M., and Krocova, S. 2013. "Řízení Vodárenských Systémů při Nedostatku Vody." Vodní hospodářství 5 (63): 156-9.

[11] Krocova, S. 2013. Strategie Územniho Plánováni v technické Infrastruktuře. Ostrava: SPBI Spektrum.

[12] Lindovsky, M., and Krocova, S. 2012. "Vodárenský dispečink jako nástroj na zvýšení provozní bezpečnosti." Vodni hospodářství 10 (62): 340-4.

[13] Bylka, H. 2002. Wodociagi i Kanalizacja w Polsce. Poznań; Bydgoszcz: Polska Fundacja Ochrony Zasobów Wodnych.

[14] ISO/IEC 16085. 2006. "Systems and Software Engineering, Life Cycle Processes, Risk Management." IEEE Xplore. Accessed March 10, 2012. http://www.iso.org/iso/catalogue_detail.

[15] AF-CityPlan s.r.o. 2014. Metodika Posuzováni Bezpečnosti Kritické Struktury-Pitná Voda (VF20102014009,14.10.2014). Document Materiál AF-CityPlan.

[16] Krocova, S. 2014. "The Water Protection Trends in the Industrial Landscape." Inžynieria Mineralna 15 (2): 171-4.

[17] Don, D. R., Malcolm, J. B., and Michael, J. 2000. Water Supply, February, 2009. London: London IWA Publishing 2000.

[18] Lindovsky, M. 2015. "Ř́zení Vodárenského Systému při Mimořádných Podmínkách.” Ph.D. thesis, The Technical University Ostrava. 